\title{
Penerapan PROPER sebagai Alat Pemicu Inovasi Teknologi Industri Berkelanjutan
}

\author{
Febri Eko Wahyudianto dan Rachmat Boedisantoso \\ 1Ilmu dan Teknologi Lingkungan, FST, Universitas Airlangga \\ 2Teknik Lingkungan, FTSP, Institut Teknologi Sepuluh Nopember (ITS) Surabaya Jl. Arif Rahman Hakim, \\ Sukolilo, Surabaya Indonesia \\ febriekow@yahoo.com
}

\begin{abstract}
Abstrak
Abstrak PROPER merupakan Program Penilaian Peringkat Kinerja Perusahaan oleh Kementerian Negara Lingkungan Hidup dan Kehutanan yang merupakan salah satu upaya untuk mendorong dan mengevaluasi penaatan perusahaan dalam pengelolaan lingkungan hidup. Metode yang diterapkan pada PROPER dilakukan secara bertahap yaitu kategori ketaatan (peringkat hitam, merah dan biru) dan lebih dari ketaatan (peringkat hijau dan emas). Kategori lebih dari ketaatan memiliki salah satu kriteria penting yaitu kriteria inovasi, dimana industri yang telah memiliki inovasi dalam pengelolaan lingkungan akan berpotensi untuk mendapatkan peringkat hijau/emas. Efektivitas PROPER dalam memicu munculnya inovasi teknologi yang ramah lingkungan dapat dilihat dengan pendekatan jumlah peserta yang ikut, peringkat yang diperoleh dan jumlah inovasi yang dihasilkan dari PROPER. Jumlah peserta PROPER 2015 mencapai 2.076 peserta yang berarti mengalami peningkatan rata-rata pertahun sebesar 28\% sejak sepuluh tahun terakhir. Persentase ketaatan peserta PROPER mengalami peningkatan hingga tahun 2015 mencapai 74\%. Peringkat lebih dari ketaatan mencapai 120 peserta dengan jumlah total inovasi yang dihasilkan sebanyak 151 inovasi diberbagai bidang seperti efisiensi energi, penurunan beban pencemar udara, 3R limbah B3, 3R limbah padat Non B3, efisiensi air dan penurunan beban pencemar air, keanekaragaman hayati, dan pemberdayaan masyarakat. Hasil menunjukkan bahwa PROPER sudah sesuai sebagai alat evaluasi dan pemicu inovasi teknologi Industri.
\end{abstract}

Kata Kunci : PROPER, Inovasi Teknologi, Industri

\section{PENDAhUluan}

Industri adalah seluruh bentuk kegiatan ekonomi yang mengolah bahan baku dan/atau memanfaatkan sumberdaya industri sehingga menghasilkan barang yang mempunyai nilai tambah atau manfaat lebih tinggi termasuk jasa industri menurut UndangUndang Republik Indonesia Nomor 3 Tahun 2014 tentang Perindustrian. Suatu kegiatan industri memiliki dampak terhadap lingkungan baik dampak positif maupun dampak negatif. Dampak positif yang ditimbulkan oleh industri lebih cenderung pada peningkatan pendapatan masyarakat, kemudahan akses fasilitas kesehatan dan peningkatan kepemilikan fasilitas [1]. Terlepas dari dampah positif yang dihasilkan, suatu kegiatan industri juga dapat menimbulkan dampak negatif.

Dampak negatif dari industri umumnya diakibatkan dari sisa proses produksi atau buangan dari proses produksi yang sering disebut sebagai limbah. Limbah yang dihasilkan dapat berupa limbah cair, gas, dan partikulat. Dampak negatif dari limbah yaitu dapat menyebabkan kekurangan oksigen pada badan air, kematian ikan, gangguan terhadap sistem ekologi, perubahan sifat-sifat air, hingga keracunan dan gangguan kesehatan pada manusia [2]. Dampak negatif yang dapat muncul akibat kegiatan industri telah dicegah atau diminimalisasi oleh pemerintah dengan adanya regulasi dalam pembuangan limbah yang dihasilkan oleh masing-masing industri. Regulasi yang ada mulai dari undangundang, peraturan pemerintah, peraturan mentri, peraturan gubernur, hingga peraturan bupati/walikota. Regulasi yang ada umumnya mengatur batasan-batasan yang harus dipenuhi oleh industri dalam pengelolaan lingkungan. Sehingga dalam pelaksanaan sebagian besar industri melakukan kegiatan pengelolaan lingkungan hanya untuk memenuhi regulasi yang ditetapkan, tidak untuk membentuk suatu budaya industri yang ramah lingkungan dan berkelanjutan. Oleh karena itu terdapat satu regulasi yang dikeluarkan oleh kementrian lingkungan hidup mengenai suatu alat untuk melakukan evaluasi terhadap kinerja industri dalam pengelolaan lingkungan yaitu PROPER.

PROPER menurut Peraturan Menteri Lingkungan Hidup Nomor 3 Tahun 2014 adalah evaluasi ketaatan dan kinerja melebihi ketaatan pertanggung jawab usaha dan/atau kegiatan dibidang pengendalian pencemaran dan/atau kerusakan lingkungan hidup serta pengelolaan limbah bahan berbahaya dan beracun. PROPER sebagai alat evaluasi ketaatan kinerja suatu kegiatan industri dibedakan menjadi tiga peringkat yaitu: hitam, merah, dan biru. PROPER selain sebagai alat evaluasi kinerja ketaatan suatu kegiatan industri terhadap regulasi juga sebagai pemicu inovasi-inovasi teknologi industri yang ramah lingkungan dan berkelanjutan dimana PROPER sebagai alat evaluasi melebihi ketaatan kinerja suatu industri dibedakan 
menjadi dua peringkat yaitu: hijau dan emas. Dalam upaya mengetahui efektifitas PROPER dalam fungsinya perlu dilakukan kajian terkait dengan jumlah peserta yang dinilai dalam PROPER, peringkat yang diperoleh, dan jumlah inovasi yang dihasilkan dalam PROPER

\section{TINJAUAN PUSTAKA}

PROPER merupakan suatu program kementrian lingkungan hidup yang telah dimullai pada tahun 2015. Awal penerapan proper berdasarkan Keputusan Mentri No. 35a Tahun 1995 tentang Program Penilaian Kinerja Perusahaan/ Kegiatan Usaha dalam Pengendalian Pencemaran dalam Lingkup Kegiatan PROKASIH (PROPER PROKASIH)[3]. PROPER dalam perjalanannya mengalami pasang surut dimana pada tahun 1998-2002 PROPER tidak dapat dilaksanakan karena krisis ekonomi dan perubahan struktur pada KLH sehingga baru mulai berjalan kembali pada tahun 2002 dengan integrasi 3 kriteria media (air, udara, dan B3)[4]. PROPER terus berkembang dengan beberapa kriteria yang ditetapkan dan terus diperbarui hingga pada tahun 2014 keluar peraturan terbaru terkait PROPER yaitu Peraturan Menteri Lingkungan Hidup Nomor 3 Tahun 2014 tentang Program Penilaian Peringkat Kinerja Perusahaan dalam Pengelolaan Lingkungan Hidup.

Definisi PROPER berdasar Peraturan Menteri Lingkungan Hidup Nomor 3 Tahun 2014 adalah evaluasi ketaatan dan kinerja melebihi ketaatan pertanggung jawab usaha dan/atau kegiatan dibidang pengendalian pencemaran dan/atau kerusakan lingkungan hidup serta pengelolaan limbah bahan berbahaya dan beracun. Evaluasi ketaatan dan melebihi ketaatan terdiri dari beberapa aspek seperti tersaji pada tabel 1. Hasil dari evaluasi PROPER akan direpresentasikan dengan peringkat yang disimbolkan menjadi lima warna yang berbeda diantaranya yaitu hitam, merah, biru, hijau, dan emas. Masing-masing warna tersebut memiliki makna yang berbeda sesuai dengan tingkat ketaatan dan upaya melebihi ketaatan yang dilakukan oleh industri seperti tersaji pada tabel 2.

Tabel 1. Aspek Penilaian PROPER Berdasarkan Peraturan Menteri Lingkungan Hidup Nomor 3 Tahun 2014

\begin{tabular}{ll}
\hline & \multicolumn{1}{c}{ Aspek } \\
\hline Ketaatan & Melebihi Ketaatan \\
\hline Pemenuhan ketentuan dalam izin lingkungan & Penerapan sistem manajemen lingkungan \\
Pengendalian pencemar air & Pencapaian dibidang efisiensi energi \\
Pengendalian pencemar udara & Pengurangan dan pemanfaatan limbah bahan berbahaya dan \\
Pengelolaan limbah bahan berbahaya dan & beracun \\
beracun & Penerapan pronsip pengurangan, penggunaan kembali dan daur \\
Pengendalian kerusakan lingkungan hidup & ulang \\
& limbah padat non bahan berbahaya dan beracun \\
& Pengurangan pencemar udara dan emisi gas rumah kaca \\
& Pencapaian dibidang efisiensi air dan penurunan beban pencemar \\
& air \\
& Perlindungan keanekaragaman hayati \\
& Pemberdayaan Masyarakat \\
\hline
\end{tabular}

Tabel 2. Peringkat PROPER Berdasarkan Peraturan Menteri Lingkungan Hidup Nomor 3 Tahun 2014

\begin{tabular}{|c|c|c|c|}
\hline No. & Aspek & Peringkat & Deskripsi \\
\hline 1 & Ketaatan & Hitam & $\begin{array}{l}\text { Penanggung jawab usaha dan/atau kegiatan yang sengaja } \\
\text { melakukan perbuatan } \\
\text { atau melakukan kelalaian yang mengakibatkan pencemaran } \\
\text { dan/atau kerusakan } \\
\text { lingkungan hidup serta pelanggaran terhadap Peraturan } \\
\text { Perundang-Undangan } \\
\text { atau tidak melaksanakan sanksi administrasi }\end{array}$ \\
\hline 2 & Ketaatan & Merah & $\begin{array}{l}\text { Penanggung jawab usaha dan/atau kegiatan yang upaya } \\
\text { pengelolaan lingkungan } \\
\text { hidupnya dilakukan tidak sesuai dengan persyaratan sebagaimana } \\
\text { diatur dalam }\end{array}$ \\
\hline & & & Peraturan Perundang-Undangan \\
\hline 3 & Ketaatan & Biru & $\begin{array}{l}\text { Penanggung jawab usaha dan/atau kegiatan yang upaya } \\
\text { pengelolaan lingkungan } \\
\text { hidupnya dilakukan sesuai dengan persyaratan sebagaimana } \\
\text { diatur dalam }\end{array}$ \\
\hline & & & Peraturan Perundang-Undangan \\
\hline 4 & Melebihi Ketaatan & Hijau & $\begin{array}{l}\text { Penanggung jawab usaha dan/atau kegiatan yang telah melakukan } \\
\text { pengelolaan }\end{array}$ \\
\hline
\end{tabular}




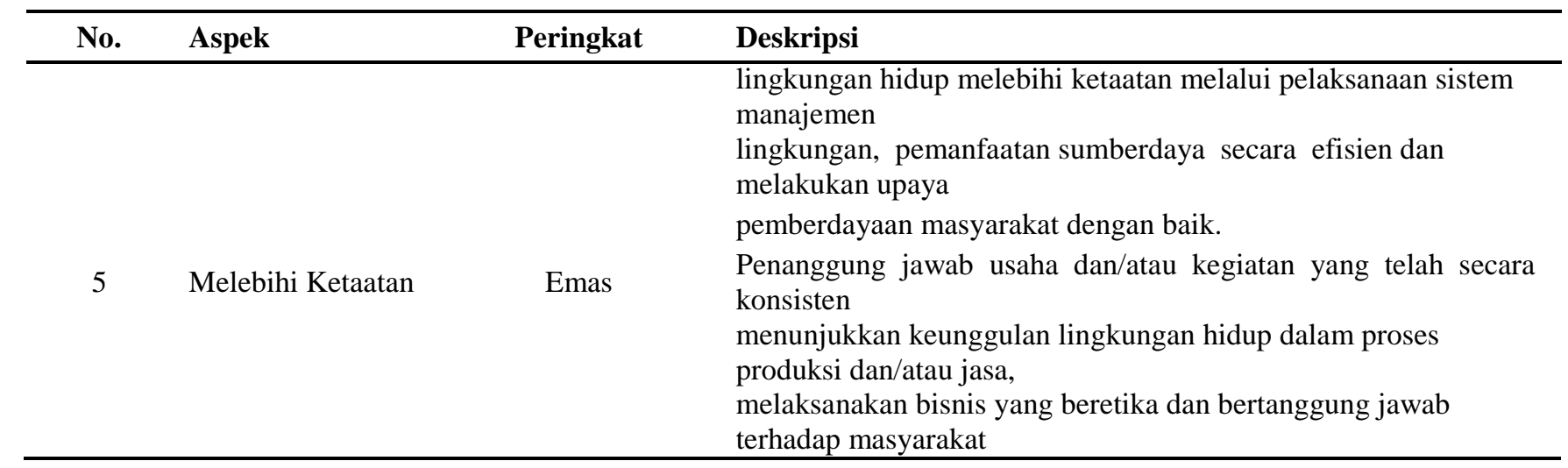

\section{METODE PENELITIAN}

Metode yang digunakan yaitu metode studi literatur. Literatur didapatkan dari regulasi yang dikeluarkan pemerintah, publikasi pemerintah terkait PROPER, dan artikel ilmiah lainnya terkait dengan PROPER serta perkembangannya. Data yang diperoleh merupakan data sekunder dari literatur. Pengolahan data dilakukan dengan mengolah data menjadi grafik kecenderungan, persebaran peringkat sesuai dengan kriteria PROPER sepuluh tahun terakhir, dan perbandingan ketaatan dari seluruh peserta PROPER.

\section{HASIL DAN PEMBAHASAN}

\subsection{Analisis Jumlah Peserta PROPER}

PROPER merupakan merupakan program pemerintah dibidang lingkungan untuk industri merupakan program sukarela (belum diwajibkan) untuk sebagian industri. Mengacu Peraturan Menteri Lingkungan Hidup Nomor 3 Tahun 2014 tentang Program Penilaian Peringkat Kinerja Perusahaan dalam Pengelolaan Lingkungan Hidup Pasal 3 menyebutkan bahwa Pelaksanaan PROPER dilakukan terhadap usaha dan/atau kegiatan wajib amdal atau UKL-UPL, yang:

1. Hasil Produksnya untuk tujuan ekspor;

2. Terdapat pada pasar bursa;

3. Menjadi perhatian masyarakat, baik dalam lingkup regional maupun nasional; dan/atau

4. Skala kegiatan signifikan untuk menimbulkan dampak terhadap lingkungan hidup

Kriteria tersebut menunjukkan bahwa tidak semua kegiatan/usaha belum diwajibkan untuk mengikuti PROPER. Berdasarkan kondisi tersebut, salah satu parameter yang dapat digunakan sebagai indikator keberhasilan PROPER yaitu jumlah Peserta PROPER. Hasil data yang didapatkan dari laporan/publikasi tahunan kementrian lingkungan hidup mulai 2004-2015 dilakukan pengolahan menghasilkan grafik peningkatan peserta PROPER seperti pada gambar 1.

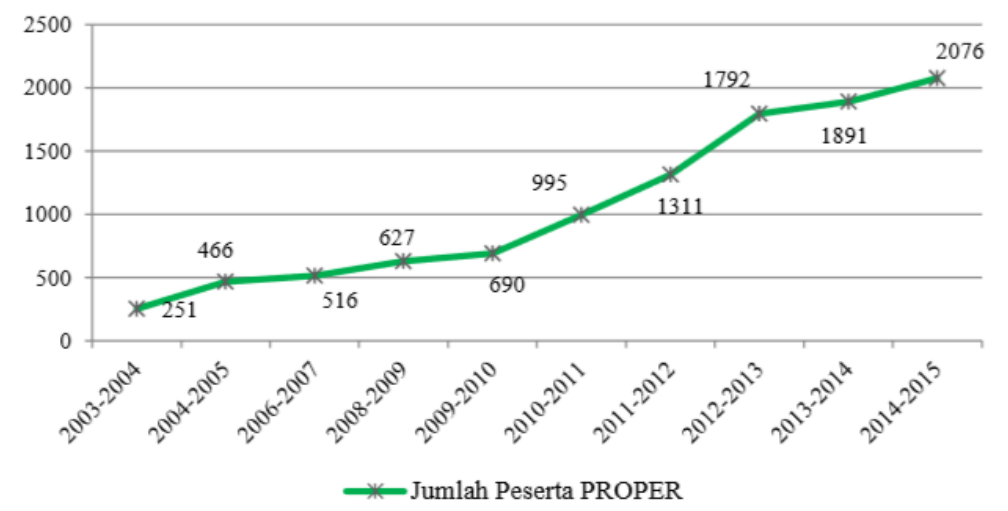

Gambar 1. Grafik Peningkatan Peserta PROPER Tahun 2004-2015

Hasil tersebut menunjukkan bahwa setiap tahun pelaksanaan PROPER selama 10 tahun terakhir mengalami peningkatan yang cukup tinggi. Periode PROPER 2003-2004 menunjukkan peserta PROPER sebesar 251 perusahaan dari seluruh Indonesia. Angka tersebut terus mengalami peningkatan pada periode 2004-2005 menjadi 446 hingga pada periode 20142015 menjadi 2.076 perusahaan yang mengikuti PROPER. Rata-rata peningkatan jumlah peserta selama 10 tahun terahir mencapai $28 \%$ pertahun. Peningkatan tersebut menunjukkan bahwa semakin bertambah banyak industri/kegiatan yang telah aware terhadap lingkungan. Hal tersebut menunjukkan bahwa pemerinta berhasil dalam menggunakan PROPER sebagai alat untuk meningkatkan kepedulian industri terhadap aspek lingkungan.

\subsection{Analisis Peringkat PROPER PROPER}

Memiliki tingkatan ketaatan atau melebihi ketaatan yang direpresentasikan menjadi lima warna peringkat yaitu hitam, merah, biru, hijau dan emas. Peringkat hitam, merah, dan biru menunjukkan tingkat ketaatan (compliance) sedangkan 
peringkat hijau dan emas menunjukkan tingkat melebihi ketaatan (beyond compliance). Pringkat PROPER tersebut juga dapat digunakan sebagai salah satu keberhasilan pemerintah dalam melakukan pembinaan kepada industri terkait dengan kepedulian terhadap aspek lingkungan. Dengan mengetahui distribusi peringkat maka dapat diketahui proporsi industri/kegiatan yang tidak taat, taat, dan melebihi ketaatan. Data dan distribusi peringkat PROPER dari tahun 2004-2015 tersaji pada tabel 3 dan gambar 2 .

Tabel 3. Data Peringkat PROPER Tahun 2004-2015 [4]-[13]

\begin{tabular}{rrrrrrrr}
\hline \multirow{2}{*}{ No. } & \multirow{2}{*}{ Tahun } & \multicolumn{6}{c}{ Peringkat } \\
\cline { 3 - 8 } & & Hitam & Merah & Biru & Hijau & Emas & Jumlah Peserta \\
\hline 1 & $2003-2004$ & 42 & 86 & 114 & 9 & 0 & 251 \\
2 & $2004-2005$ & 72 & 150 & 221 & 23 & 0 & 466 \\
3 & $2006-2007$ & 42 & 83 & 344 & 46 & 1 & 516 \\
4 & $2008-2009$ & 56 & 130 & 399 & 41 & 1 & 627 \\
5 & $2009-2010$ & 47 & 152 & 435 & 54 & 2 & 690 \\
6 & $2010-2011$ & 49 & 283 & 552 & 106 & 5 & 995 \\
7 & $2011-2012$ & 79 & 330 & 771 & 119 & 12 & 1.311 \\
8 & $2012-2013$ & 17 & 611 & 1.039 & 113 & 12 & 1.792 \\
9 & $2013-2014$ & 21 & 516 & 1.224 & 121 & 9 & 1.891 \\
10 & $2014-2015$ & 21 & 529 & 1.406 & 108 & 12 & 2.076 \\
\hline
\end{tabular}

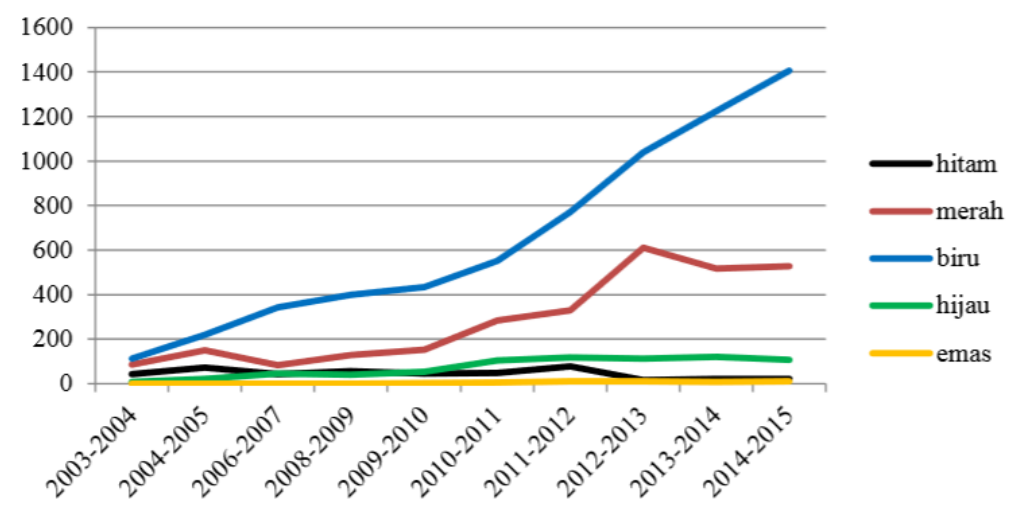

Gambar 2. Grafik Distribusi Peringkat PROPER Tahun 2004-2015

Data dan distribusi peringkat PROPER berdasarkan tabel 1 dan grafik distribusi pada gambar 2 menunjukkan bahwa sebagian besar peserta PROPER mendapatkan peringkat biru yang berarti industri tersebut taat dengan regulasi yang ditetapkan dimana industri telah melakukan pengelolaan lingkungan dan memenuhi standar yang berlaku. Peringkat merah menempati peringkat kedua terbanyak dimana industri pada peringkat merah telah melakukan pengelolaan lingkungan tetapi belum secara total $(100 \%)$ memenuhi standar yang berlaku. Kondisi industri yang mendapatkan peringkat merah inilah yang harus dilakukan pembinaan untuk mendorong industri meningkatkan kualitas pengelolaan lingkungan sehingga dapat mencapai pengelolaan yang baik (100\% memenuhi standar). Industri yang mendapatkan peringkat hitam atau industri yang belum melakukan pengelolaan lingkungan dari tahun ke tahun telah dapat ditekan jumlahnya sehingga memiliki trend menurun pada tahun 2015.

Peringkat hijau dan emas (beyond compliance) merupakan peringkat yang menunjukkan industri tersebut tidak hanya sekedar memenuhi peraturan, tetapi industri pada peringkat ini memiliki komitmen lebih terhadap lingkungan. Jumlah industri yang mendapat peringkat hijau memiliki trend yang cukup baik dengan mengalami peningkatan dari tahun ketahun dengan persentase sebesar 5\% (108 peserta) pada tahun 2015 sedangkan peringkat emas sebesar $1 \%$ (12 peserta) seperti pada gambar 3. Industri pada peringkat ini selalu berupaya untuk peduli terhadap lingkungan dengan menerapkan sistem manajemen lingkungan, efisiensi sumber daya, dan melakukan kegiatan pemberdayaan masyarakat (community development). Industri yang mendapat peringkat hijau dan emas juga telah menerapkan inovasi-inovasi dalam proses produksi maupun penunjang untuk mengefisiensikan kegiatan yang ada sehingga dapat mengurangi beban pencemar yang ada dan mendapatkan nilai lebih dari penurunan biaya produksi. 


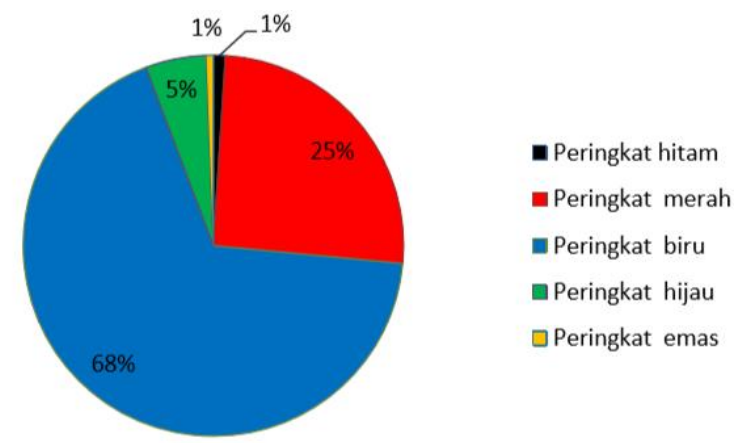

Gambar 3. Proporsi Peringkat PROPER Tahun 2015

Selain dari distribusi dan proporsi peringkat PROPER, analisis dapat dilakukan berdasarkan persentase ketaatan (peringkat biru, hijau, dan emas). Persentase dapat dihitung dengan menggunakan rumus (1) sebagai berikut:

$$
\% \text { Ketaatan }=\frac{(\text { jumlah industri peringkat biru,hijau,emas })}{\text { (jumlah peserta PROPER })},
$$

Dengan menggunakan rumus tersebut dapat didapatkan data persentase ketaatan tiap tahun. Data yang didapatkan diplot dalam grafik mulai tahun 2004 hingga 2015 untuk mengetahui trend \%ketaatan selama 10 tahun terakhir. Hasil analisis yang dilakukan tersaji pada gambar 4. Hasil menunjukkan bahwa \%ketaatan 10 tahun terakhir berkisar antara 49\%-76\%. Semakin tinggi \%ketaatan yang diraih mengindikasikan bahwa industri yang ada di Indonesia semakin taat dengan regulasi yang berlaku. Sebagai contoh pada tahun 2015 tingkat ketaatan mencapai $74 \%$ yang berarti bahwa $74 \%$ industri yang mengikuti PROPER pada tahun 2015 mendapatkan peringkat biru, hijau, dan emas sedangkan $26 \%$ peserta mendapat peringkat merah dan hitam atau tidak taat. Data tersebut dapat dijadikan sebagai acuan untuk mendorong $26 \%$ industri yang tidak taat untuk dilakukan pembinaan sehingga diharapkan pada tahun berikutnya menjadi industri yang taat terhadap regulasi yang berlaku.

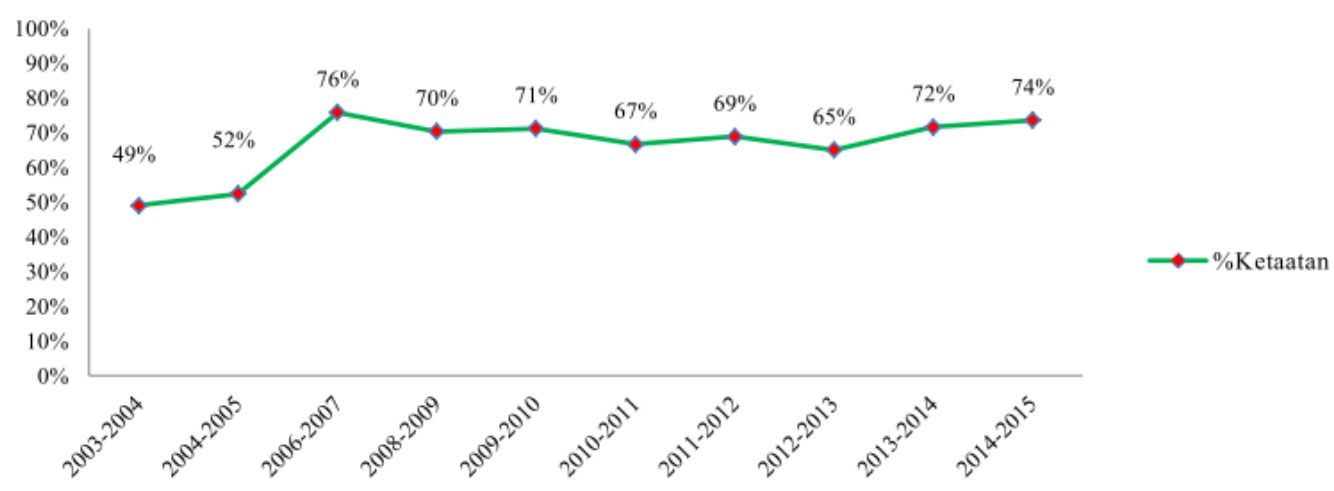

Gambar 4. Persentase Ketaatan (Peringkat Biru, Hijau, dan Emas) PROPER Tahun 2004-2015

\subsection{Inovasi Industri}

PROPER merupakan suatu alat (tools) evaluasi yang kompleks dimana dapat mengakomodir seluruh regulasi pemerintah dan aspek lingkungan lain yang tidak diatur dalam regulasi pemerintah. Hal tersebut yang membuat PROPER dapat meningkatkan kualitas pengelolaan lingkungan industri yang ada di Indonesia. Salah satu aspek penting dalam PROPER yakni inovasi. Inovasi merupakan aspek yang penting bagi industri untuk terus melakukan perubahan yang lebih baik disegala aspek baik produksi dan penunjang sehingga meningkatkan daya saing industri tersebut. Mengacu Peraturan Menteri Lingkungan Hidup Nomor 3 Tahun 2014 tentang Program Penilaian Peringkat Kinerja Perusahaan dalam Pengelolaan Lingkungan Hidup lampiran 5 kriteria Dokumen Ringkasan Kinerja Pengelolaan Lingkungan (DRKPL), PROPER mengapresiasi industri yang melakukan inovasi baik di proses produksi maupun penunjang dimana industri yang memiliki inovasi mendapatkan nilai lebih dalam penilaian PROPER.

Inovasi yang dihasilkan oleh industri juga didorong untuk meningkatkan inovasi tersebut menjadi lebih tinggi berupa hak paten. PROPER juga mengapresiasi hak paten yang didapatkan oleh industri dengan memberikan nilai lebih tinggi berupa nilai adisionalitas dan nilai paten. PT Badak NGL merupakan salah satu industri yang menjadikan inovasi yang dikembangkan menjadi paten. Inovasi yang menjadi paten tersebut yaitu "T-Plug instaler" dalam aspek efisiensi energi dan penurunan beban emisi, "Draying oven" dalam aspek 3R limbah B3 dan 3R limbah padat non B3, dan "Biskuit dari tepung cangkang kepiting" dalam aspek pemberdayaan masyarakat [4]. Adanya inovasi yang mendapatkan paten tersebut diharapkan dapat memberikan kontribusi nyata baik bagi industri maupun stakeholder lain yang terkait.inovasi yang dihasilkan pada periode PROPER tahun 2015 tercatat sebanyak 151 inovasi yang telah dikembangkan oleh 120 industri di Indonesia yang mendapat peringkat melebihi ketaatan [13]. Inovasi-inovasi yang telah dihasilkan oleh berbagai industri seperti pada tabel 4. 
Tabel 4. Inovasi yang telah Dilakukan oleh Industri [4], [13]

\begin{tabular}{|c|c|c|c|}
\hline No. & Program & Industri & Keterangan \\
\hline 1. & T-Plug instaler & PT Badak NGL & Inovasi - Paten \\
\hline 2. & Draying oven & PT Badak NGL & Inovasi - Paten \\
\hline 3. & $\begin{array}{l}\text { Biskuit dari tepung cangkang } \\
\text { kepiting }\end{array}$ & PT Badak NGL & Inovasi - Paten \\
\hline 4. & $\begin{array}{l}\text { Pertanian hidroponik Masyarakat } \\
\text { Pangalengan }\end{array}$ & $\begin{array}{l}\text { Star Energy Geothermal } \\
\text { Wayang Windu Ltd }\end{array}$ & Inovasi \\
\hline 5. & $\begin{array}{l}\text { Teknologi listrik hybrid di area } \\
\text { kantor }\end{array}$ & $\begin{array}{l}\text { PT Pertamina (Persero) TBBM } \\
\text { Rewulu }\end{array}$ & Inovasi \\
\hline 6. & $\begin{array}{l}\text { Eco-driving dengan software } \\
\text { android }\end{array}$ & $\begin{array}{l}\text { PT Pertamina (Persero) TBBM } \\
\text { Rewulu }\end{array}$ & Inovasi \\
\hline 7. & $\begin{array}{l}\text { Alat sterilisasi jamur } \\
\text { menggunakan uap geothermal }\end{array}$ & $\begin{array}{l}\text { PT Pertamina Geothermal } \\
\text { Energy }\end{array}$ & Inovasi \\
\hline 8. & $\begin{array}{l}\text { Smart Exhaust Air Conditioning } \\
\text { (AC) }\end{array}$ & $\begin{array}{l}\text { PT Pertamina (Persero) TBBM } \\
\text { Rewulu }\end{array}$ & Inovasi \\
\hline 9. & $\begin{array}{l}\text { Portable turbine dan bladeless } \\
\text { turbine }\end{array}$ & $\begin{array}{l}\text { PT Pertamina Geothermal } \\
\text { Energy }\end{array}$ & Inovasi \\
\hline
\end{tabular}

\section{KESIMPULAN}

Penerapan PROPER di Indonesia menunjukkan efektifitas dalam mendorong industri dalam pengelolaan lingkungan dengan ditandai banyaknya peserta PROPER pada tahun 2015 sebesar 2.076 perusahaan dengan rata-rata peningkatan keikutsertaan sebesar $28 \%$ pertahun. Peringkat PROPER terdistribusi menjadi $1 \%$ peringkat hitam, $25 \%$ peringkat merah, $58 \%$ peringkat biru, 5\% peringkat hijau, dan $1 \%$ peringkat emas. Persentase ketaatan peserta PROPER tahun 205 mencapai $74 \%$ dengan jumlah inovasi sebesar 151 inovasi dari 120 industri berperingkat hijau dan emas. Hasil tersebut menunjukkan bahwa PROPER telah sukses menjadi suatu alat evaluasi pengelolaan lingkungan dan pemicu inovasi teknologi industri berkelanjutan.

\section{DAFTAR PUSTAKA}

[1] S. Nawawi, I., Ruyadi, Y., Komariah, "Pengaruh Keberadaan Industri Terhadap Kondisi Sosial Ekonomi dan Budaya Masyarakat Desa Lagadar Kecamatan Marga Asih Kabupaten Bandung,” J. Sosietas, vol. 5, 2015.

[2] Supraptini, "Pengaruh Limbah Industri Terhadap Lingkungan di Indonesia," Media Litbang Kesehat., vol. 5, p. 1019, 2002.

[3] A. Reliantoro, S., Arsyad, I., Prihantono, D. S., Karim, M. A., Kusrihadi, Gunawan, Y., Susanti, N., Parwitosari, A., Khoirunisa, I., Nuryandain, D., Busori, Dwiastoro, The Gold For Green: Bagaimana Penghargaan PROPER Emas Mendorong Lima Perusahaan Mencapai Inovasi, Pencipataan Nilai dan Keunggulan Lingkungan. Jakarta: Kementerian Lingkungan Hidup, 2012.

[4] Kementerian Lingkungan Hidup, “Keputusan Menteri Lingkungan Hidup dan Kehutanan Republik Indonesia Nomor 180 Tahun 2014 Tentang Hasil Penilaian Peringkat Kinerja Perusahaan dalam Pengelolaan Lingkungan Hidup 2013-2014," 2014.

[5] Kementerian Lingkungan Hidup, "Press Briefing PROPER 2014,” 2004.

[6] Kementerian Lingkungan Hidup, “Press Release Hasil Penilaian PROPER 2004-2005,” 2005.

[7] Kementerian Lingkungan Hidup, “Press Release Hasil Penilaian PROPER 2006-2007,” 2007.

[8] Kementerian Lingkungan Hidup, "Laporan Hasil Penilaian Peringkat Kinerja Perusahaan Dalam Pengelolaan Lingkungan Hidup PROPER 2008-2009,” 2009.

[9] Kementerian Lingkungan Hidup, "Laporan Hasil Penilaian Peringkat Kinerja Perusahaan Dalam Pengelolaan Lingkungan Hidup 2010,” 2010.

[10] Kementerian Lingkungan Hidup, "Laporan Hasil Penilaian Peringkat Kinerja Perusahaan Dalam Pengelolaan Lingkungan Hidup," 2011.

[11] Kementerian Lingkungan Hidup, Keputusan Menteri Lingkungan Hidup Republik Indonesia Nomor 273 Tahun 2012. 2012.

[12] Kementerian Lingkungan Hidup, "PROPER 2013 Program Penilaian Peringkat Kinerja Perusahaan Menyemai Kebijakan, Melindungi Lingkungan,” 2013.

[13] Kementerian Lingkungan Hidup, "PROPER Program Penilaian peringkat Kinerja Perusahaan Dalam Pengelolaan Lingkungan hidup 2015,” 2015. 